\title{
Nature as a blind space
}

\section{An ambiguous concept}

What does the word nature exactly represent in such an expression as "state of nature", which is precisely what knits up the whole demonstration in the second discourse? Rousseau explicitly refers himself to a twofold tradition: the recent, but clearly delineated tradition represented by the jus-naturalists and law philosophers ${ }^{1}$; but also the older and less conspicuous one held by the scholastics and theologians:

\footnotetext{
"It did not even occur to most of ours - i.e. our French philosophers - to doubt the possibility for a state of nature to have existed, whereas it is obvious, when one reads the sacred books, that, having received immediate enlightenment and precepts from God, the first man was not himself in that state, and when one adds to Moses' writings the faith owed to them by all Christian philosophers, one must deny that, even before the Flood, men should ever have found themselves in the pure state of nature, unless they had fallen back into that state in consequence of some extraordinary event."2
}

From the state of nature, understood as the state of man in nature, as opposed to the state of man in society, Rousseau has slipped to the state of pure nature, which refers to the status purae naturae that one comes across in the works of Thomas Aquinas' commentators, Cajetanus, Suares and mostly Jansen, who places that notion at the heart of his Augustinus.

1 See Robert Derathé, Jean-Jacques Rousseau et la science politique de son temps, Vrin, 1979, and Victor Goldschmidt, Anthropologie et politique. Les principes du système de Rousseau, Vrin, 1974, notably p. 217sq.

2 "Il n'est pas même venu dans l'esprit de la plupart des nôtres [= de nos philosophes français] de douter que l'Etat de Nature eût existé, tandis qu'il est évident, par la lecture des Livres Sacrés, que le premier Homme, ayant reçu immédiatement de Dieu des lumieres et des Preceptes, n'étoit point lui-même dans cet état, et qu'en ajoutant aux Ecrits de Moïse la foi que leur doit tout Philosophe Chrétien, il faut nier que, même avant le Deluge, les Hommes se soient jamais trouvés dans le pur état de Nature, à moins qu'ils n’y soient retombés par quelque Evenement extraordinaire." (p. 132. All my references are from Jean Starobinski's édition of CEuvres Complètes, vol. III, « Écrits politiques », Gallimard, Pléiade, 1964.) 
The entirely hypothetical character of the state of pure nature, from which man has immediately fallen into a state of corrupted nature, status naturae lapsae, comes from the scholastics; and the mode of reasoning consisting in making use of an hypothetical, an unreal, category, in order to deduce from it a certain type of organization, of arrangement of the real, is a scholastic mode of reasoning.

Now, what does the word nature refer to in the theological concept of "the state of nature"? It is neither to nature as displayed before our eyes, nor to Nature as a principle of organization of the world, but to a state of nature specific to man, to the original nature of man, to what man is by nature:

"Religion /.../ does not forbid us to form conjectures, derived from the mere nature of man and of the creatures that surround him, upon what mankind might have become, if man had remained abandoned to his own self."3

This abandonment is the abandonment of man without God; it hypothesizes a purely logical development of man, without Providence, a necessary hypothesis in order to establish, by contradistinction, the intervention of God through Grace, within the Christian reality that we are witnesses of: to the theological status naturae is opposed the status gratiae, which Rousseau makes a very slight allusion to here by appropriating the same structure and mode of reasoning, but emptied of its original content, as Hobbes had already done before him. ${ }^{4}$

Nature therefore does not refer to the world, to a certain state of the world in which one should imagine the first men living; nature is a logical category, as one distinguishes between the nature and the function of a noun in grammar, as when Rousseau, at the end of

3 "La religion [...] ne nous défend pas de former des conjectures tirées de la seule nature de l'homme et des Etres qui l'environnent, sur ce qu'aurait pu devenir le Genre-humain, s'il fût resté abandonné à lui-même.” (p. 133. Here, in a note, Jean Starobinski sends us back to Suarez, de Gratia, Prol. 4, c.1, n.2, who himself quotes Cajetan.)

4 Yves-Charles Zarka, Hobbes et la pensée politique moderne, PUF, 1995, 2000. 
his second discourse, discusses "the nature of the fundamental pact of all governments" (p. 184), "the nature of the Contract" (p. 185). Nature is an abstract tool that sends us back to a non-existent origin, that one has to postulate, but that cannot be represented:

"At last, in their endless talk of need, greed, oppression, desire and pride, all have transferred to the state of nature ideas they had borrowed from society. They were talking of savage man when what they were painting was civil man /.../. The research one can pursue in this field should not be taken for historical truths, but only for hypothetical and conditional reasoning, better suited to clarify the nature of things as they are than to show their true origin, not unlike those daily offered by our physicians upon the formation of the world."5

We are here confronted with the properly literary subtlety of the Discourse, which does not merely reject one mode of reasoning in favor of another, but which superimposes one upon the other and starts from this "extremely embarrassing paradox" to build its own representation from this logical impossibility.

On the one hand therefore, taken as a moral display of the human passions (such as need, greed, oppression... etc), the state of nature is a visual delusion in which the other philosophers' discourses get caught and founder; on the other hand, the nature of things, that the hypothesis of the state of nature serves to clarify, becomes visible only if the hypothesis that makes it intelligible is maintained throughout as a logical impossibility.

"They were talking of savage man when what they were painting was civil man": when discourse becomes painting, when it makes us see what it says, it is our current human condition, the current stage of our world that we see, in a false, painted, scenery. It is not possible "to show the true origin": the nature of the state of nature can be apprehended only

5 "Enfin tous, parlant sans cesse de besoin, d'avidité, d'oppression, de desirs, et d'orgueil, ont transporté à l'état de Nature des idées qu'ils avoient prises dans la société. Ils parloient de l'Homme Sauvage, et ils peignaient l'homme Civil. [...] Il ne faut pas prendre les Recherches, dans lesquelles on peut entrer sur ce Sujet, pour des vérités historiques, mais seulement pour des raisonnements hypothétiques et conditionnels; plus propres à éclaircir la Nature des choses, qu’à en montrer la véritable origine, et semblables à ceux que font tous les jours nos Physiciens sur la formation du Monde." (p. 132-3) 
in the indirect convolutions of "hypothetical and conditional reasoning". It cannot be offered to sight or staged since to stage nature is merely to project our own world. We are therefore left on the one side with a theatrical space, a stage, where we are, in the civilized actuality of the world and, on the other side, with an abstract, logical but invisible space, where to localize nature for want of visualizing an origin. Here Nature makes up for the lack of origin and can be patterned as the backstage of the world, constituting what we shall call a blind space.

\section{The impossibility to see}

We do not, we cannot see that space and, at the same time, we are required to have a mental image of it: "how will man at last manage to see himself as nature formed him?" (p. 122), Rousseau asks in his Preface. But then he immediately states that seeing such a thing is impossible: "let not my readers imagine that I dare flatter myself with having had a sight of what I deem to be so difficult to see" (p. 123). Instead of seeing, one must therefore imagine an indirect method, putting into play "reasoning" and "conjectures" in order to determine "what experiments would be required in order to reach full knowledge of natural man." 6

This method is defined in contra-distinction from reading:

"Leaving therefore all scientific books which teach us to see men only as they have made themselves, and pondering over the first and simplest operations of the human soul, I seem to perceive two principles that are anterior to reason ..."

6 Jean Starobinski has shown how seeing is prohibited in Les Confessions ( L'OEil vivant, Gallimard, 1961, p. 93sq.). Is it this autobiographical prohibition of desire that is objectified here in a philosophical formulation, or is it on the contrary a kind of theologico-political device, through which Rousseau organizes his conception of nature, that is projected into Les Confessions as a prohibition to see?

7 "Laissant donc tous les livres scientifiques qui ne nous apprennent qu'à voir les hommes tels qu'ils se sont faits, et méditant sur les premières et plus simples opérations de l'âme humaine, j’y crois apercevoir deux principes antérieurs à la raison...” (p. 125-6) 
Scientific book reading makes us see only a staging of the present human condition. On the contrary, private meditation turns our eyes inward and demands that man should "at last manage to see himself as he was formed by nature": eyes then seem to perceive "two principles anterior to reason". Turning our eyes inward, piercing through the coatings of reason (the disfigurements of Glaucus' statue, p. 158, the successive developments through which reason "has managed at last to smother Nature", p. 162), allows us to have a peep this side of the visible, where principles lie. What is there cannot be read, nor can it offer itself to reading.

Unless there exists another book:

"Oh man, whatever your country, whatever your opinions, listen to me; here is your history such as I seem to have read it, not in the books of your fellow-men that are liars, but in nature that never lies." 8

Nature is now defined as a space, and not as a mere category, a space that is not offered to eyes as a show but, nevertheless, can be read and submitted to conjecture. A space that would serve as a virtual book, and compensate our blindness.

Within that space, Rousseau first refuses to describe man, as we see at the beginning of the first part of the second Discourse:

"I shall not trace his organization through his successive developments, I shall not stop at looking into the animal System to see what he may have been at the start /.../; I shall not examine whether, as Aristotle thinks, his long nails were not first hook-like claws"9

Nature is a blind space: trying to see it is pointless and Rousseau makes it clear that it is not to be attempted: the origin is not to be looked at; better still, the examining of nature is

8 "O Homme, de quelque Contrée que tu sois, quelles que soient tes opinions, écoute; voici ton histoire telle que j'ai cru la lire, non dans les Livres de tes semblables qui sont menteurs, mais dans la Nature qui ne ment jamais." (p. 133)

9 “je ne suivrai point son organisation à travers ses devéloppemens successifs : Je ne m'arrêterai pas à rechercher dans le Systême animal ce qu'il put être au commencement [...]; Je n'examinerai pas, si, comme le pense Aristote, ses ongles alongés ne furent point d'abord des griffes crochües .” (p. 134) 
necessarily preceded by the solemn denial of a visible origin, by the claim that any visible show of original nature is an impossibility.

It is a double negative that introduces the embryonic description of the original man, which is there only to tell us that we must renounce seeing him, because he is himself deprived of sight:

"I shall not examine /.../ whether, his walking on all fours, his eyes directed upon the ground and their range limited to a distance of a few steps, did not mark both the character and the limited range of his ideas." 10

To this limited horizon that prevents man in the state of nature from seeing and that we cannot see from our own world, to this space upon which we can only form "vague, almost imaginary, conjectures", Rousseau opposes his own hypothesis, which he boldly puts forward as a false hypothesis, offering a postulated origin, a visible substitute for its impossible visibility:

"I shall suppose him (man) conformed from all time as I see him today, walking on two feet, using his hands as we do ours, holding the whole of Nature under his gaze, and using his eyes to measure the vast expanse of the sky." ${ }^{11}$

Nature at last shows itself as a spectacle. Man, using his eyes to measure up the vast expanse of the sky, thus delineating the range and extent of his own ability to see, is opposed to the original quadruped whose ground-bound and limited sight only marked out the emptiness of his ideas. The spectacle of nature is necessary in order to conceive the state of nature; but it is impossible, both because we project it from our own corrupted humanity and because the natural man could not see it:

10 “Je $n$ 'examinerai pas [...] si marchant à quatre pieds, ses regards dirigés vers la Terre, et bornés à un horizon de quelques pas, ne marquoient point à la fois le caractere, et les limites de ses idées .” (ibid.)

11 “je le supposerai [le = l'homme] conformé de tous tems, comme je le vois aujourd'hui, marchant à deux pieds, se servant de ses mains comme nous faisons des nôtres, portant ses regards sur toute la Nature, et mesurant des yeux la vaste étendue du Ciel." (ibid.) 
"His imagination does not paint anything for him /.../. The spectacle of nature becomes indifferent to him, by dint of becoming too familiar /.../ he does not have the mental ability to wonder at the greatest marvels; and it is not in him that one should look for the Philosophy that man needs, in order to know how to observe once what he sees every day."12

One should be able to observe what the natural man saw. But the natural man had no consciousness of seeing anything. One must therefore substitute for him a hypothetical man, "conformable from all time" and capable of observing a spectacle the natural man was not aware of.

Further on, Rousseau evokes Mandeville and his fable of the Bees. Mandeville provides him with a figure for this impossible original gaze:

"The pathetic image of an imprisoned man who perceives outside a ferocious beast tearing an infant from its mother's bosom, breaking the feeble limbs with its murderous teeth and tearing away the throbbing entrails of this child with its claws. What an awful commotion is it not for this witness of an event in which he takes no personal interest? What anguish doesn't he suffer at the sight, for being unable to go to the rescue of the fainting woman and the expiring infant ${ }^{13}$ ? Such is the pure movement of Nature, anterior to all reflection"14

This parable, found in a book, provides an image for the principle of pity that, together with the love of oneself, Rousseau, at the beginning of the second Discourse, felt he perceived

12 "Son imagination ne lui peint rien [...]. Le spectacle de la Nature lui devient indifférent, à force de lui devenir familier. [...] il n'a pas l'esprit de s'étonner des plus grandes merveilles; et ce n'est pas chez lui qu'il faut chercher la Philosophie dont l'homme a besoin, pour savoir observer une fois ce qu'il a vû tous les jours ." (p. 144)

13 Should we connect this image with that offered by the frontispiece engraving of the Lettre sur les sourds that Diderot had published in 1751 ?

14 "la pathétique image d'un homme enfermé qui apperçoit au-dehors une Bête féroce arrachant un Enfant du sein de sa Mére, brisant sous sa dent meurtriére les foibles membres, et déchirant de ses ongles les entrailles palpitantes de cet Enfant. Quelle affreuse agitation n'éprouve point ce témoin d'un évenement auquel il ne prend aucun intérêt personnel ? Quelles angoisses ne souffre-t-il pas à cette veüe, de ne pouvoir porter aucun secours à la Mére évanouie, ni à l'Enfant expirant?

Tel est le pur mouvement de la Nature, antérieur à toute réflexion.” (p. 154-5) 
after he had discarded all books... One can see that thought is always submitted to a double constraint and deliberately superimposes two contradictory modes of conceptualization, at once exacting visibility and stating invisibility, proclaiming and denying the necessity of conjecture; and, for this conjecture to operate, both using and proscribing the model of books and reading. Mandeville's parable makes it possible to articulate this double movement.

Man in the state of nature is related to an imprisoned man who, from his prison cell, witnesses a performance in which he can have no active part. The relative positions of the prisoner watching the scene where the lion devours the child is analogous to what the audience witnesses in a dark or dimly lighted theatre, facing an illuminated, plainly visible, stage. Like the prisoner in his cell, the spectator is not personally concerned or endangered by what is happening before him. Like the cell bars, the invisible fourth wall between the stage and the audience allows them to see, but not to interfere in the play. Reciprocally, the woman and child do not realize that they are watched; the prisoner remains as invisible to them as the spectators to the characters in a play; he is not in the place of the action; his place is only a point of vantage directed outward, towards the place of the action, towards the object of the performance, where the infant is being devoured by a lion.

The state of nature, the inside of the prison cell, escapes description; or rather such a description would be pointless. What Rousseau is concerned with here is no longer the "pure state of nature", but the "pure movement of nature"; in other words the point is not to describe the inside of the prison cell, but to give an account of what attracts the prisoner to this external spectacle which is yet supposed to be totally alien to him. The blind space of nature (represented by the cell) is the place where the act of seeing takes its origin; but the birth of this faculty of seeing projects the person that sees outside of nature, into the movement of 
history, towards social horror. The emergence of society as a visible, theatrical space prepares the way to de-naturation and corruption.

\section{The civil is the visible}

The second part of the Discourse starts with a space-enclosing gesture:

"The first person that, having enclosed a piece of land, bethought himself of declaring, this is mine, and found sufficiently simple minded people to believe him, was the true founder of civil society"15

Beyond the symbolic and philosophical bearing of this gesture which identifies the social state with a state of property ownership, this alteration of the relationship between man and space plays a decisive part in the passage from the blindness of nature to the visibility of society ${ }^{16}$. A man marks off a piece of land, settles down upon it and makes a speech, This is mine, in front of an audience, "people that are simple minded enough to believe him", who are from then on forbidden any access to this property, this scenic space. The foundation of society is the foundation of a scenic space; the civil organization is a theatrical organization.

At the same time, the process of conceptualization, which had so far been marked by the impossibility to see and by the working and tension of conjecture, now undergoes a radical change of model: a point of view is now established, in order to face a visible picture.

"Let us therefore take things from a higher vantage point and try to gather within a single point of view this slow succession of events and discoveries, in their most natural order." 17

15 "Le premier qui ayant enclos un terrain, s'avisa de dire, ceci est à moi, et trouva des gens assés simples pour le croire, fut le vrai fondateur de la société civile." (p. 164)

16 Scenic visibility, in Rousseau's thought, is always manifested as a consequence of a previously blind state. See Jean-Christophe Sampieri's analysis of chapter I of l'Essai sur l'origine des langues, in Résistance de l'image, PENS, TIGRE, 1992 , p.225-244, notably p.231.

17 "Reprenons donc les choses de plus haut et tâchons de rassembler sous un seul point de vue cette lente succession d'évenemens et de connoissances, dans leur ordre le plus naturel..” (ibid.) 
At the same time as the philosopher gathers, unites, and orders the component parts of a social scene that he will thus be able to make us see, the historical process itself of the constitution of societies is described as a process of gathering, circumscribing, and connecting, in radical opposition to the process of dissemination that characterized the state of nature. In the state of nature, men were "dispersed" (p. 135), they lived "scattered among the beasts" (p. 136) "and as there was hardly any other means to keep together than not to lose sight of one another, they were soon almost in a state of not even recognizing one another" (p. 147): dissemination is an essential character of the blind space, bearing the same relationship to the social state of property as, in classical painting, the vague space of the real surrounding, to the scene, the inner stage of the representation.

When an embryo of society emerges in nature, the faculty of looking manifests itself as directed from the space of nature towards this scenic enclosure circumscribing a civil organization, in the same way as the powerless gaze of the prisoner towards the lion devouring the child, or the stupefied gaze of the savages in front of the first man that, having enclosed a piece of land, bethought himself of declaring this is mine.

Society emerges from this marking out of limits, but also from a process of gathering, of assembling individuals together: it was "the effect of a new situation that gathered husbands and wives, fathers and children, within a common dwelling" (p. 168); they are now "men thus brought together, and forced to live together" (p. 169); they "gradually come closer together, gather in various groups" (ibid.); to the initial scattering there succeeds a linking process, "a few links between various families" (ibid.), "the linkages increase and the links become tighter" (ibid.)

History is a synthetic, and therefore a scenic, ordering of what nature offered as a scattering: 
"things having reached this point, it is easy to imagine the rest. /.../ I shall limit myself only to casting a glance at the human species placed within this new order of things." 18

This ease of casting a glance is opposed to the delusions and impossibilities among which conjectures about the state of nature were getting lost. Here the philosopher can exert his scanning look, at the very moment when the gathering of men together and the beginning of relationships between them make the faculty of looking possible in the civil community. It first manifests itself as looking at oneself, which degrades the love of oneself into self-love:

"Then the first time he looked at himself, he felt his first motion of self-pride; then, hardly distinguishing among the respective ranks of beings, and finding himself in the first rank on account of his species, he found himself by far prepared to pretend to this rank on account of his own individual self." ${ }^{\prime 9}$

Looking is a splitting faculty that divides being and seeming and thus leads the way to the great stage of the civilized world and, by this means, introduces the leaven of corruption:

"Each man began looking at the others and wishing to be looked at /.../; and the fermenting process initiated by this new leaven finally produced aggregates that were baleful to happiness and innocence" 20

From then on, within society itself, the faculty of looking will degenerate and precipitate the social state towards a return to the blindness of nature. Rousseau speaks of a circle, of that "extreme point that closes the circle, adjoining the point from which we started" (p. 191).

18 "Les choses étant parvenües à ce point, il est facile d'imaginer le reste. [...] Je me bornerai seulement à jetter un coup d'œil sur le Genre-humain placé dans ce nouvel ordre de choses.” (p. 174)

19 "C'est ainsi que le premier regard qu'il porta sur lui-même, y produisit le premier mouvement d'orgueil ; c'est ainsi que sachant à peine distinguer les rangs, et se contemplant au premier par son espéce, il se préparoit de loin à y prétendre par son individu.” (p. 166)

20 "Chacun commença à regarder les autres et à vouloir être regardé soi-même [...]; et la fermentation causée par ces nouveaux levains produisit enfin des composés funestes au bonheur et à l'innocence." (p. 170) 


\section{Panoptical vision and blinded vision}

Yet it is not exactly a return to the same situation as at the beginning of the Second discourse: the blinded state of the enslaved and corrupted men — "the eyes of the People /.../ fascinated" by their leaders (p. 188) - manifests itself as a picture to the wise man's eyes, to those "few great cosmopolitan souls, who can step over the imaginary barriers that divide the peoples of the world and who, following the example of the sovereign being that created them, embrace the whole of Mankind within their benevolence." (p. 178)

The erroneous, split up, blinded vision, is itself enfolded within a larger device, as one component piece of the conceptual picture that is being built around the love of freedom.

"The politicians make the same sophistic discourses upon the love of freedom as the philosophers upon the state of nature; from the things they see they judge of very different things that they have not seen and they attribute to men a natural leaning towards servitude from the patience with which those they have under their eyes bear their own"21

Concerning the love of freedom, that breaks out within the state of society as the demand of a return to nature, Rousseau once more finds the same blindness of the philosophers that he had condemned at the beginning of the second discourse, concerning the state of nature. They implement the same transposition of the current delusion they are surrounded with, into a prior situation, a state that utterly differs from their world. In appearance therefore the loop is looped: the social picture is blurred and the splitting effect of its visibility brings back the civil space of representation to its initially scattered state of nature.

Yet, the very parallel between the love of freedom and the state of nature introduces a new operative device: the love of freedom is not a state, but a movement from the civil state

21 "Les politiques font sur l'amour de la liberté les mêmes sophismes que les Philosophes ont faits sur l'Etat de Nature ; par les choses qu'ils voyent ils jugent des choses très différentes qu'ils n'ont pas vues et ils attribuent aux hommes un penchant naturel à la servitude par la patience avec laquelle ceux qu'ils ont sous les yeux supportent la leur.” (p. 181) 
towards nature, that is a means, from the social space, which is the current visible one, to see this state of nature despite the blindness and the native paradox it is connected with. The love of freedom does not bring back the primal blindness; it pictures the movement towards that blindness and, by this means, makes the state of nature indirectly visible.

"As an untamed horse bristles up its mane, stamps the earth with its hoof and struggles impetuously at the mere approach of the bit, whereas a trained horse suffers whip and spur with patience, the barbarian does not bend his head under the yoke that the civilized man bears without a murmur of complaint, and prefers the most stormy freedom to the tranquillity of servitude."22

The revolt of the Barbarian who refuses civilization is incomprehensible to the politicians who measure his nature and his behavior from what they are used to seeing, that is peoples whom civilization has reduced to a debased state of servility. The revolted Barbarian springs up as a symptom of the state of nature that they can't a priori understand, because it is irreducible to semiotic apprehension within the social space. In order to make it visible on the stage of representation, Rousseau resorts to the subterfuge of culture, which provides him with the images that our corrupt and weakened world could not offer him: the double epic metaphor of the untamed racehorse and of the trained horse introduces the difference between the two states within the sphere of the visible, and thus makes the state of nature visible from the state of society within which it introduces a claim for freedom through protest and revolt. However this double image must not induce us to simply juxtapose the two concepts: it is within the trained horse itself that one must descry the untamed one, within the civilized man, the original Barbarian and, within the sea-eroded statue, the primal Glaucus. To

22 “Comme un coursier indompté hérisse ses crins, frappe la terre du pied et se débat impétueusement à la seule approche du mords, tandis qu'un cheval dressé souffre patiemment la verge et l'éperon, l'homme barbare ne plie point sa tête au joug que l'homme civilisé porte sans murmure, et il préfere la plus orageuse liberté à un assujettissement tranquille." (ibid.) 
the philosopher's eye the social state is a screen that enfolds the state of nature, not only in order to make it invisible, but that corrodes, corrupts and disfigures it. ${ }^{23}$

Visibility can therefore only arise as far as we understand and keep in mind this superimposition, which makes it possible to conjecture the primal state of nature from the social symptom, through the exercise of philosophical indignation. What comes into play then is another seeing eye than the deluding and deluded eye of the moralists and politicians, a revolted eye :

"but when I see the others sacrificing pleasures, peacefulness, wealth, power and life itself to the preservation of this one good that is so despised of those that have lost it /that is freedom/; when I see animals, that were born free and that abhor their captivity, break their skulls against the bars of their prison, when I see multitudes of naked Savages disdaining the European pleasures and braving hunger, fire, sword and death in order to keep no more than their independence, I feel that Slaves are not fit to reason about freedom." ${ }^{24}$

What Rousseau sees is unintelligible, and Rousseau himself sees it only at the cost of his own exclusion from the civil community, which he denounces as a community of slaves. These senseless, unseemly pictures, accede to visibility for the reader only within the movement of the Rousseauist revolt, which is a movement outward, towards nature. Rousseau still keeps his social eye at his disposal but, transporting his mind into the state of nature, he disengages himself from the delusions that go with that eye; he has not yet entirely quitted the social

23 See Jean Starobinski's analysis of the myth of Glaucus in La Transparence et l'obstacle, Gallimard, 1971, Tel, p. 27 sq.

24 "mais quand je vois les autres sacrifier les plaisirs, le repos, la richesse, la puissance et la vie même à la conservation de ce seul bien si dédaigné de ceux qui l’ont perdu [= la liberté] ; quand je vois des Animaux nés libres et abhorrant la captivité se briser la tête contre les barreaux de leur prison, quand je vois des multitudes de Sauvages tout nuds mépriser les voluptés Européennes et braver la faim, le feu, le fer et la mort pour ne conserver que leur indépendance, je sens que ce n'est pas à des Esclaves qu'il appartient de raisonner de liberté." (p. 181-2) 
sphere of the visible, but he has now sufficiently detached himself from it to bring into a fully conscious play the splitting power of its difference, figured by the metaphor of the two horses.

This allows a better understanding of the frontispiece engraved in 1755 by Sornique, from a drawing by Eisen. Eisen took his subject from an obscure anecdote from the History of Travels collated by Prévost and recorded at the end of the first and longest note of the second part of Rousseau's Discourse. In the late seventeenth century, the governor of Cape town, Simon van der Stel, adopted a young Hottentot savage, had him richly dressed, instructed in several languages and made him travel to the Indies. Upon his return, the young man visited a few Hottentots of his family:

"He decided to strip himself of his European attire and to clothe in a ewe's pelt. He returned to the fort in this new garb, holding a parcel containing his former clothes and, as he handed them to the Governor, he addressed him thus: Do me the kindness, sir, of taking note that I renounce this attire for ever. For the rest of my life I also renounce the Christian religion, my resolve being to live according to the religion, the uses and manners of my ancestors. The only grace that I solicit from you is that I may keep the collar and the knife that I am wearing. I shall keep them for the love of you. Upon which, without waiting for Van der Stel's answer, he stole away and took flight and was never seen again in Cape town. History of Travels, book 5, p.175.”25

On the foreground of the engraving, the heap of clothes that the Hottentot has come to return functions as a symptom, pointing both to the sloughing of civilization and to the move back to nature ${ }^{26}$. Above, the young man, wrapped in the skin of a ewe, points at the rejected

25 “il prit le parti de se dépouiller de sa parure Européenne pour se révêtir d'une peau de Brebis. Il retourna au Fort, dans ce nouvel ajustement, chargé d'un pacquet qui contenoit ses anciens habits, et les présentant au Gouverneur il lui tint ce discours: Ayez la bonté, Monsieur, de faire attention que je renonce pour toûjours à cet appareil. Je renonce aussi pour toute ma vie à la Religion Chrétienne, ma resolution est de vivre et mourir dans la Religion, les maniéres et les usages de mes Ancêtres. L'unique grace que je vous demande est de me laisser le Collier et le Coutelas que je porte. Je les garderai pour l'amour de vous. Aussi-tôt sans attendre la réponse de Van der Stel, il se déroba par la fuite et jamais on ne le revit au Cap. Histoire des voyages, Tome 5, p. 175." (Note XVI, p. 221)

26 See the frontispiece. 
clothes with his right arm, in accompaniment to his speech and, with his left hand, at the coast and the outer space of the sea crowded with boats, as vanishing point of his flight and return to his homeland. On the left, Van der Stel is sitting and meditating in front of his counselors, who wear a hat and are awaiting his answer,

At the back of this left side, clouds are gathering above the Dutch fort.

Within the space of representation, there is no place for nature, at the very moment when the Hottentot, in the name of freedom, insists on returning to the state of nature with his parents and community. The heap of clothes, the governor and his counselors assembled as spectators of the scene offered to them by the young man, the fort and the boats, in fact all his environment, inscribe him within the civil society that he claims to be flying from. Even the outward space of the sea is swarming with Dutch boats. Only the flying movement and the preliminary doffing of the clothes, on the threshold of the scenic space, point to the blind space of nature. In Moreau the Younger's version of the scene, the outer space is peopled with Hottentots but they are busy working for the Dutch. In Marillier's version, the emphasis is laid upon the young man's flight, running past the heap of clothes. But looking back as he is towards his audience in the pose of an opera dancer, he seems to be destined never to escape. In order to conceive and represent this anthropological space of nature, it will be necessary to break from the classical scenographic frame of its representation. 